\title{
The effects of ultrasound and shockwave treatment on muscle regional oxygen saturation using near-infrared spectroscopy
}

\author{
Wpływ terapeutycznej fali ultradźwiękowej i uderzeniowej na regionalną oksymetrię tkanki \\ mięśniowej ocenianej z zastosowaniem metody spektroskopii bliskiej podczerwieni
}

\author{
Anna Lubkowska ${ }^{\circledR}$, Aleksandra Radecka ${ }^{1}$, Miłosz Parchimowicz', Iwona Bryczkowska ${ }^{1}$, Monika Chudecka ${ }^{2}$ \\ 1 Pomorski Uniwersytet Medyczny w Szczecinie, Zakład Diagnostyki Funkcjonalnej i Medycyny Fizykalnej, ul. Żołnierska 54, 71-210 Szczecin \\ Pomeranian Medical University in Szczecin, Department of Functional Diagnostics and Physical Medicine \\ ${ }^{2}$ Uniwersytet Szczeciński, Katedra Anatomii Funkcjonalnej Człowieka i Biometrii, ul. Cukrowa 12, 71-004 Szczecin \\ University of Szczecin, Department of Human Functional Anatomy and Biometry \\ $\checkmark$ anna.lubkowska@pum.edu.pl
}

\begin{abstract}
Introduction: Therapeutic pressure waves are often used to treat various musculoskeletal disorders but the biological effect is still not fully known. This study investigating the effects of sound waves of different stimulus strength used in ultrasound therapy (UST) and radial extracorporeal shockwave therapy (rESWT) treatments on muscle oxygen saturation and surface temperature in terms of the trophic effect, using near-infrared spectroscopy. Materials and methods: 41 healthy volunteers including 27 ones treated with UST and 14 ones treated with rESWT: aged 22-48 years. Oxygen saturation and surface temperature measurements of the infraspinatus muscle region were repeated 4 times: immediately before $\left(\mathrm{T}_{0}\right)$ and after the treatment $\left(\mathrm{T}_{1}\right)$, and $15 \mathrm{~min}\left(\mathrm{~T}_{2}\right)$ and $30 \mathrm{~min}$ after the treatment $\left(\mathrm{T}_{3}\right)$. Muscle oxygen saturation was measured at 2 depths: $20 \mathrm{~mm}$ (sensor $1-\mathrm{S}_{1}$ ) and $12.5 \mathrm{~mm}$ (sensor $2-\mathrm{S}_{2}$ ).
\end{abstract}

\section{ABSTRAKT}

Wstęp: Terapeutyczne fale ciśnieniowe są często stosowane w leczeniu różnych schorzeń układu mięśniowo-szkieletowego, niemniej jednak efekt biologiczny ich odziaływania wciąż nie został w pełni poznany. W przedstawionych badaniach oceniono wpływ fal dźwiękowych o różnej sile bodźca stosowanych w terapii falą ultradźwiękową (ultrasound therapy - UST) i pozaustrojową radialną falą uderzeniową (radial extracorporeal shockwave therapy - rESWT) na wysycenie tlenem tkanki mięśniowej i temperaturę powierzchniową w kontekście potencjalnego efektu troficznego przy użyciu spektroskopii bliskiej podczerwieni (near-infrared spectroscopy).

Materiały i metody: Badaniem objęto 41 zdrowych ochotników, w tym 27 poddanych UST i 14 rESWT, w wieku 22-48 lat. Pomiar saturacji tkankowej i temperatury powierzchni obszaru mięśnia podgrzebieniowego wykonano 4-krotnie: bezpośrednio przed $\left(\mathrm{T}_{0}\right)$ i po $\left(\mathrm{T}_{1}\right)$ oraz $15\left(\mathrm{~T}_{2}\right)$ i $30 \mathrm{~min}$ po aplikacji bodźca $\left(\mathrm{T}_{3}\right)$.
\end{abstract}

Results: The value of regional oxygen saturation $\left(\mathrm{rSO}_{2}\right.$ [\%]) statistically significantly decreased immediately after 15 and 30 min following the treatment in the subjects treated with UST. The baseline values, amounting to $71.26 \pm 5.47 \%\left(\mathrm{~S}_{1}\right)$ and 88.26 $\pm 2.89 \%\left(\mathrm{~S}_{2}\right)$ for respective depths, significantly decreased following the treatment to $68.89 \pm 5.26 \%\left(\mathrm{~T}_{2}\right)$ and $68.93 \pm 5.12 \%\left(\mathrm{~T}_{3}\right)$ at a measuring depth of $20 \mathrm{~mm}$ and to $86.63 \pm 5.37 \%\left(\mathrm{~T}_{1}\right)$ and $86.52 \pm 3.38 \%\left(\mathrm{~T}_{2}\right)$ at a measuring depth of $12.5 \mathrm{~mm}$.

Conclusions: The results obtained indicate only the treatment with UST has a significant effect on changes in regional oximetry, which induces deep hyperaemia and increased temperature of the deeper tissues, promoting the de-dissociation of oxygen from haemoglobin to tissues, inducing the trophic effect.

Keywords: near infrared spectroscopy; near-infrared spectroscopy; ultrasound therapy; extracorporeal shockwave therapy.

Saturacje mięśni zmierzono na 2 głębokościach: 20 mm (czujnik 1 - $\mathrm{S}_{1}$ ) i 12,5 mm (czujnik $2-\mathrm{S}_{2}$ ).

Wyniki: Wartość regionalnej perfuzji tkankowej $\left(\mathrm{rSO}_{2}\right.$ [\%]) istotnie zmniejszyła się natychmiast oraz po 15 i $30 \mathrm{~min}$ od UST. Wartości początkowe, wynoszące $71,26 \pm 5,47 \%\left(\mathrm{~S}_{1}\right)$ i $88,26 \pm 2,89 \%$ $\left(\mathrm{S}_{2}\right)$ dla odpowiednich głębokości, znacząco spadły po bodźcowaniu odpowiednio do $68,89 \pm 5,26 \%\left(\mathrm{~T}_{2}\right)$ i $68,93 \pm 5,12 \%\left(\mathrm{~T}_{3}\right)$ na głębokości $20 \mathrm{~mm}$ i 86,63 $\pm 5,37 \%\left(\mathrm{~T}_{1}\right)$ i 86,52 $\pm 3,38 \%\left(\mathrm{~T}_{2}\right)$ na głębokości 12,5 mm.

Wnioski: Uzyskane wyniki wskazują, że tylko leczenie za pomocą UST ma znaczący wpływ na zmiany oksymetrii regionalnej, co tłumaczy się ich działaniem przekrwiennym i termicznym w tkankach głębokich, które z kolei indukują dysocjacje tlenu $\mathrm{z}$ hemoglobiny do tkanek i efekt troficzny.

Słowa kluczowe: spektroskopia bliskiej podczerwieni; spektroskopia bliska podczerwieni; terapia ultradźwiękowa; terapia falą ultradźwiękową; terapia pozaustrojową falą uderzeniową.

\section{INTRODUCTION}

Pressure waves (or sound waves) have been used in medicine for many years as both diagnostic and therapeutic tool $[1,2]$. The influence of pressure waves on biological tissues relate primarily to mechanical production of molecular vibrations. Mechanical waves cause direct effects in the form of increased cellular metabolism, transmembrane diffusion processes, and stimulation of microcirculation [3, 4]. Mechanical vibrations 
are accompanied by the so called cavitation effects manifested by the formation, assembly and burst of gas bubbles in the variable pressure field $[5,6,7]$. The collapse of larger bubbles generates a shockwave of extremely high local temperature $\left(10^{4} \mathrm{~K}\right)$, which - in the case of uncontrolled cavitation - may result in tissue breakdown $[2,3,4,5,6,7]$. Each transducer produces a unique acoustic field pattern due to the particular vibration conditions of the piezoelectric disks related to their manufacturing process. These variations in the radiation pattern influence the temperature distributions and could be the cause of unexpected acoustic radiations [8]. The amount of produced heat depends both on the wave parameters and the properties of the medium through which the wave travels. Among the most important factors affecting the strength of the acoustic stimulus, there are its local concentration in a given area of tissues, stimulation time, tissue suppression ability, and ambient thermal conductivity $[3,4]$. One of the branches of medicine being a particular area of the therapeutic utilisation of sound waves is medical rehabilitation where pressure waves are used most often in 2 treatment variants, i.e. ultrasound therapy (UST) $[2,9]$ and extracorporeal shockwave therapy (ESWT) [10,11]. The therapeutic application of UST uses intensities between 1 and $3 \mathrm{~W} / \mathrm{cm}^{2}$, divided into waves emitted in a continuous or pulsed ultrasound waveform $[2,9$, $12,13]$. A continuous waveform produces in the tissue $100 \%$ of heat for a given acoustic power, whereas a pulsed one is characterised by limited thermal effects depending in the value of pulse duty factor (pulse duration to pulse period). However, the thermal effect also depends on other protocol parameters, such as treatment dose, frequency, time and size of the treatment area $[13,14,15]$. Although the shockwave is a type of therapeutic acoustic wave, it is significantly different from UST. This is a special type of non-linear pressure wave, characterised by a short rise time; the total duration of a shockwave is around $10 \mu$ [11]. Because of this, the biological effects and treatment protocols are different from UST. Extracorporeal shockwave therapy is classified into focused ESWT and defocused (radial) ESWT (rESWT) [10, 11], the latter being used in the present study. A rESWT device generates a pressure field extending to $40 \mathrm{~mm}$ in water but we do not know how these measures relate to biological tissue [11]. The application of therapeutic acoustic waves refers to diseases and dysfunctions of soft tissues, including muscle tissue, which is based on many years of research. For example, with respect to UST, their local effect on: altered membrane permeability, increased protein synthesis, mast cell degranulation, growth factor production, calcium uptake, and fibroblast mobility has been proved $[16,17,18,19$, 20], whereas with respect to ESWT, among others, on pain relief, tissue regeneration and destruction of calcifications [10, 11]. The proposed beneficial effects of mechanical waves also relate to improved vascularisation, nutrition and metabolism of the tissues being stimulated, but still there is little research clearly supporting these theses $[19,20]$. The metabolism and nutrition of tissues are closely linked to their energy production and degree of their oxygenation. A potential method allowing estimation of the trophic effect of stimuli impact on tissues seems to be near infrared spectroscopy (NIRS), used to assess tissue oxygenation (saturation/perfusion) [21]. A NIRS device consists of a light-source emitting 2 or more wavelengths of light in the near-infrared range (650-1000 $\mathrm{nm}$ ) into the tissue of interest and a detector placed at a known distance from the source(s) [21]. Electromagnetic near-infrared wavelength radiation penetrates the tissues laying immediately under a sensor; the measurement of regional oxygen saturation $\left(\mathrm{rSO}_{2}\right)$ is done by chromatophore photon absorption $[22,23]$. The absorbance of near infra-red light differs depending on the amounts of oxygenated- or deoxygenated-state chromatophore haemoglobin in small blood vessels (arterioles, capillaries and venules) and myoglobin [21, 24]. With this system, the measurement of oxidative metabolism, and blood flow in various human tissues, including the brain and skeletal muscle, is possible, which has gained widespread use, among others, in anaesthesiology, intensive therapy, and emergency medical services [21, 22, 23]. Recently, there has been a growing interest in using the NIRS system to evaluate the oxygen saturation of muscle tissue in the physiological and pathological states, e.g. rhythmic exercise, muscle myopathies, diseases causing muscle atrophy, heart failure, and peripheral arterial (or vascular) disease [21, 25, 26]. It also seems that the use of near-infrared spectroscopy methods gives new possibilities for non-invasive and objective assessment of the therapeutic effects of physiotherapy treatments. The objective of this study was to investigate the trophic effect of a single sound wave impact in UST and rESWT treatments on soft tissues through estimation of muscle oxygen saturation using NIRS. According to our knowledge, this is the first study on the application of NIRS to investigate the effect of physiotherapy treatments on $\mathrm{rSO}_{2}$ level.

\section{MATERIALS AND METHODS}

The study was conducted at the Department of Functional Diagnostics and Physical Medicine (DFDPM), Pomeranian Medical University in Szczecin (PMU) in Poland. Each of the participants signed a written informed consent before taking part in the study according to the Declaration of Helsinki. The study was approved by the local Ethics Committee of the PMU (protocol number: KB-0012/36/13). The research was carried out under the projects of "Young Researchers" and "Statutory Activities" of the DFDPM, implemented in the period of 2014-2017. It was financed by the grants of the Ministry of Science and Higher Education obtained by Faculty of Health Sciences of the PMU (number of projects: MB-318-202/16/17; MB-318-06/15; WNoZ318-01/S/13; WNoZ-318-02/S/13).

The study group consisted of 41 healthy volunteers (18 men and 23 women), aged 22-48 years. All participants had given their informed consent for participation in the research study. As a starting point, each of the study participants underwent a physical examination in order to identify possible contraindications for treatments.

Next, the subjects being qualified were randomly divided into 2 groups exposed to a single physiotherapy treatment: 
TABLE 1. The characteristics of the study groups

\begin{tabular}{lcc}
\multicolumn{1}{c}{ Treatment } & UST & rESWT \\
\hline & $\mathrm{n}=27(\mathrm{~W}=14 ; \mathrm{M}=13)$ & $\mathrm{n}=14(\mathrm{~W}=9 ; \mathrm{M}=5)$ \\
\hline Age (years) & $30.38 \pm 14.31$ & $27.86 \pm 1.99$ \\
\hline Body weight $(\mathrm{kg})$ & $73.50 \pm 12.94$ & $68.50 \pm 15.11$ \\
\hline Body height $(\mathrm{cm})$ & $176.08 \pm 9.30$ & $175.79 \pm 10.79$ \\
\hline BMI $\left(\mathrm{kg} / \mathrm{m}^{2}\right)$ & $24.23 \pm 2.76$ & $22.62 \pm 2.97$ \\
\hline
\end{tabular}

UST - ultrasound therapy; rESWT - radial extracorporeal shock wave therapy; W-women; $M$ - men

group 1 - to UST treatment, and group 2 - to rESWT treatment, respectively. The 2 groups did not differ statistically in terms of age and body weight. The characteristics of the study groups is presented in Table 1 .

All treatments were performed to the same body region - the posterior part of the shoulder joint, about $2 \mathrm{~cm}$ below the scapular spine, i.e. to the infraspinatus muscle region. The study was performed at the same time of day for all participants (8-10 a.m.). Before the treatment, each of the study participants underwent a 20-minute acclimation in a seated position with the bare region of the body to be treated, then body surface temperature of the chosen region was measured and muscle tissue oxygenation $\left(\mathrm{rSO}_{2}\right)$ with a NIRS using Sensmart-NIRS X-1000 (Nonin Medical B.V. Prins Hendriklaan 26, 1075 BD Amsterdam, Netherlands) was estimated. For each subject, thermography was performed using a Therma CAM SC500 thermal imaging camera (FLIR System, Inc., 16 Esquire Road, North Billerica, MA 01862.), providing long-wave imaging ( 7.5 to $13 \mu \mathrm{m}$ ) performance with a thermal sensitivity of $0.1^{\circ} \mathrm{C}$. The value of skin emissivity was adopted as 0.98 . The study was conducted according to standards set by the European Thermographic Association. The room (approximately $12 \mathrm{~m}^{2}$ area), was closed, with a constant ambient temperature and humidity which were maintained at the same level during the measurement period. There were no draughts or influences of air conditioning. There was a low intensity natural lighting. A computerised image analysis system allowed determination of the measuring area of the body surface, with the mean surface temperature ( $\mathrm{T}$ mean) of the designated area being chosen for analysis. The measurement analysis used were Agema Report 5.4.1 and Agema Report Viewer 5.4. The $\mathrm{T}$ mean was obtained for the chosen region; it was deemed more representative for the entire region than minimum and maximum values.

To estimate muscle oxygen saturation, a NONIN 7600 apparatus was used with 2 types of Equanox sensors:

1. Model $8003 \mathrm{CA}, 3$-wavelength, depth of measurement $\sim 20 \mathrm{~mm}$.

2. Model $8004 \mathrm{CB}, 4$-wavelength, depth of measurement $\sim 12.5 \mathrm{~mm}$.

Baseline measurements, before the treatment, were marked as $\mathrm{T}_{0}$. Next, one of the planned treatments, with strictly defined parameters, the same in each subject, was performed. The used stimulation parameters, which are regarded as strong, applied to a chronic condition, are summarised in Table 2.
TABLE 2. The stimulation parameters

\begin{tabular}{lll}
\multicolumn{2}{c}{ Treatment } & \multicolumn{1}{c}{ Dose } \\
\hline $\begin{array}{lll}\text { UST } \\
\text { ultrasound therapy }\end{array}$ & $\begin{array}{l}\text { Zimmer } \\
\text { Physys } \\
5 \mathrm{~cm}^{2}\end{array}$ & $\begin{array}{l}\text { the power setting } 1.5 \mathrm{~W} / \mathrm{cm}^{2} \\
\text { duration of a treatment } 5 \mathrm{~min} \\
\text { frequency of } 0.8 \mathrm{MHz} \\
\text { fill factor }=100 \%\end{array}$ \\
\hline $\begin{array}{l}\text { rESWT } \\
\text { radial extracorporeal } \\
\text { shock wave therapy }\end{array}$ & Rosetta & $\begin{array}{l}2.5-3.5 \text { bar } \\
2000 \text { strokes } \\
\text { frequency of } 5-10 \mathrm{~Hz}\end{array}$ \\
\hline
\end{tabular}

UST - ultrasound therapy; rESWT - radial extracorporeal shock wave therapy

Following the treatment, the measurements were repeated three times in each subject, i.e. immediately after the treatment $\left(\mathrm{T}_{1}\right)$, and $15 \mathrm{~min}\left(\mathrm{~T}_{2}\right)$ and $30 \mathrm{~min}\left(\mathrm{~T}_{3}\right)$ after the treatment. In the period between successive measurements, the subjects rested in a seated position with the bare treated region of the body at thermal comfort temperature.

\section{RESULTS}

In the study being presented here, 2 types of sensors were used to assess changes in regional muscle oxygen saturation of the stimulated tissue for which, as specified by manufacturer, haemoglobin oxygen saturation is measured at a depth of $\sim 20 \mathrm{~mm}\left(\mathrm{~S}_{1}\right)$ and $\sim 12.5 \mathrm{~mm}\left(\mathrm{~S}_{2}\right)$. It can be seen that mean baseline $\mathrm{rSO}_{2}$ differed, depending on the reading depth. For the depth of $20 \mathrm{~mm}$ (corresponding to the muscle tissue), the mean value was $71.26 \pm 5.47 \%$ in group 1 and $70.17 \pm 4.61 \%$ in group 2, whereas for the depth of $12.5 \mathrm{~mm}$ (corresponding to the adipose tissue), this value was $88.26 \pm 2.89 \%$ and $87.17 \pm 2.62 \%$, respectively (Table 3 and 4 ). The mean surface temperature of the analysed regions was $34.04 \pm 1.12^{\circ} \mathrm{C}$ in group 1 and 33.71 $\pm 0.62^{\circ} \mathrm{C}$ in group 2 . There were no statistically significant differences between groups with respect to the baseline values of the analysed parameters. Table 3 summarises the results for the changes in surface temperature and regional oximetry in the group of subjects exposed to UST treatment, whereas Table 4 presents the results obtained in the group of subjects exposed to rESWT treatment. Following the application of ultrasound therapy, a significant but temporary decrease in the mean oxygen saturation was observed immediately after and $15 \mathrm{~min}$ after the treatment at a depth of $12.5 \mathrm{~mm}(\mathrm{p}<0.05)$, and a sustained decrease in oxygen saturation 15-30 min after the treatment at a depth of $20 \mathrm{~mm}(p<0.01)$. It should be noted that these changes were accompanied by a decrease in surface temperature of the analysed region $\left(\mathrm{T}_{1}, \mathrm{~T}_{2}, \mathrm{~T}_{3}\right)$. When analysing the effects of mechanical energy in rESWT treatment, a transient decrease in surface temperature of the assessed region was found immediately after the treatment $(p<0.05)$, probably due to the mechanical friction intensively occurring during the wave application with the pneumatic method, and a significant decrease in oxygen saturation level not until $30 \mathrm{~min}$ after the treatment and only at a depth of $20 \mathrm{~mm}$. Body surface temperature returned to the values comparable with baseline ones as early as $15 \mathrm{~min}$ after the treatment. In the treatment procedure, the option of coupling gel application 
TABLE 3. The results for the changes in surface temperature and regional oximetry in the group of subjects exposed to ultrasound therapy treatment

\begin{tabular}{|c|c|c|c|c|}
\hline$n=27$ & $\mathrm{~T}_{0}$ & $T_{1}$ & $\mathrm{~T}_{2}$ & $\mathrm{~T}_{3}$ \\
\hline $\begin{array}{l}\mathrm{S}_{1} \mathrm{rSO}_{2}(\%) \\
\text { (depth of measurement } \sim 20 \mathrm{~mm} \text { ) }\end{array}$ & $71.26 \pm 5.47$ & $70.22 \pm 5.6$ & $\begin{array}{c}68.89 \pm 5.26 \downarrow \\
* * T_{0 p}=0.004628 \\
* T_{1 p}=0.034492\end{array}$ & $\begin{array}{l}68.93 \pm 5.12 \downarrow \\
* * T_{0 p}=0.003218\end{array}$ \\
\hline $\begin{array}{l}\mathrm{S}_{2} \mathrm{rSO}_{2}(\%) \\
\text { (depth of measurement } \sim 12.5 \mathrm{~mm} \text { ) }\end{array}$ & $88.26 \pm 2.89$ & $\begin{array}{l}86.63 \pm 5.37 \downarrow \\
* T_{0 p}=0.010324\end{array}$ & $\begin{array}{l}86.52 \pm 3.38 \downarrow \\
\star * T_{0 p}=0.003989\end{array}$ & $87.63 \pm 2.75$ \\
\hline $\mathrm{T}$ mean $\left({ }^{\circ} \mathrm{C}\right)$ & $34.04 \pm 1.12$ & $\begin{array}{l}30.22 \pm 1.16 \downarrow \\
* * * T_{0}\end{array}$ & $\begin{array}{c}32.32 \pm 1.20 \uparrow \\
* * * T_{1}\end{array}$ & $\begin{array}{c}32.66 \pm 1.28 \uparrow \\
* * * T_{1}\end{array}$ \\
\hline
\end{tabular}

$\mathrm{T}_{0}$ - before the treatment; $\mathrm{T}_{1}$ - after the treatment; $\mathrm{T}_{2}-15$ min after; $\mathrm{T}_{3}$ - 30 min after; $\mathrm{S}_{1}$ - sensor $1 ; \mathrm{S}_{2}$ - sensor 2; $\mathrm{T}$ mean - the mean surface temperature; ${ }^{*} \mathrm{p}<0.05 ;{ }^{* *} \mathrm{p}<0.01 ;{ }^{* * *} \mathrm{p}<0.001$

TABLE 4. The results for the changes in surface temperature and regional oximetry in the group of subjects exposed to radial extracorporeal shock wave therapy treatment

\begin{tabular}{|c|c|c|c|c|}
\hline$n=14$ & $T_{0}$ & $\mathrm{~T}_{1}$ & $\mathrm{~T}_{2}$ & $\mathrm{~T}_{3}$ \\
\hline $\begin{array}{l}\mathrm{S}_{1} \mathrm{rSO}_{2}(\%) \\
\text { (depth of measurement } \sim 20 \mathrm{~mm} \text { ) }\end{array}$ & $70.17 \pm 4.61$ & $71.25 \pm 4.73$ & $72.83 \pm 6.6$ & $\begin{array}{c}69.5 \pm 4.7 \downarrow \\
* T_{2 p}=0.026232\end{array}$ \\
\hline $\begin{array}{l}\mathrm{S}_{2} \mathrm{rSO}_{2}(\%) \\
\text { (depth of measurement } \sim 12.5 \mathrm{~mm} \text { ) }\end{array}$ & $87.17 \pm 2.62$ & $88.08 \pm 4.12$ & $87.42 \pm 5.93$ & $88.08 \pm 3.23$ \\
\hline $\mathrm{T}$ mean $\left({ }^{\circ} \mathrm{C}\right)$ & $33.71 \pm 0.62$ & $\begin{array}{c}34.58 \pm 1.06 \uparrow \\
* T_{0}\end{array}$ & $34.21 \pm 0.81$ & $33.82 \pm 0.75$ \\
\hline
\end{tabular}

$\mathrm{T}_{0}$ - before the treatment; $\mathrm{T}_{1}$ - after the treatment; $\mathrm{T}_{2}-15$ min after; $\mathrm{T}_{3}-30$ min after; $\mathrm{S}_{1}-$ sensor $1 ; \mathrm{S}_{2}-$ sensor $2 ; \mathrm{T}$ mean - the mean surface temperature; ${ }^{*} \mathrm{p}<0.05$

was deliberately abandoned as it could decrease skin temperature, disturbing at the same time the measurement itself (Table 4), which could not be applied, according the treatment procedure, in the case of UST.

\section{DISCUSSION}

Therapeutic pressure waves are often used to treat various musculoskeletal disorders as they are assumed to have thermal and mechanical effects on the target tissue resulting in an increased local metabolism and microcirculation, decreased pain and muscle tension, inhibition of muscle spasms, and accelerated healing $[1,9,10,11,16,19,27]$. At present, with the development and availability of precise research techniques in medicine, the assessment of possible therapeutic effect of physical therapy treatments including their dosage should be based on the objective findings of examination, supplemented by the evaluation of patient's medical condition and his/her subjective feelings. It therefore seems important to search for a diagnostic method that allows for a realistic assessment of the improvement of tissue metabolism, being one of the major objectives of physical therapy treatments $[16,19]$. Tissue nourishment is inextricably associated with the efficiency of the cardiovascular system, therefore the methods assessing the vascular flow might be useful. When selecting an appropriate method, its specific nature should be considered, for example ankle-brachial index, Doppler ultrasonography, or computed tomography angiography refer to large blood vessels where increased vascular flow does not reflect changes in microcirculation $[25,28]$. On the other hand, the available methods of microcirculation assessment, e.g. laser Doppler flowmetry or $\mathrm{TcPO}_{2}$, do not evaluate the actual gas exchange and the same the improvement of tissue metabolism with oxygen [29, 30, 31]; in this case, NIRS seems to be a useful tool. It is a non-invasive technique that uses the differential absorption properties of haemoglobin to evaluate tissue oxygenation. This method has been used primarily as a research tool to assess dynamic changes in the status of tissue oxyhaemoglobin, deoxyhaemoglobin, total blood (haemoglobin) volume and the oxidation state of the copper moiety of mitochondrial cytochrome $c$ oxidase (cytochrome $\mathrm{a}_{1} \mathrm{a}_{3}$ ) in brain and muscle [21, 24, 32]. The measurement is based on the relative ease with which near infrared light (700-1000 $\mathrm{nm}$ ) penetrates through biological tissues, including bone, skin and muscle and allows for detection of changes in light-absorbing chromophores (haemoglobin, myoglobin and cytochrome c oxidase) in human in vivo [25,33]. It is assumed that changes in haemoglobin and myoglobin oxygenation are an expression of the difference between the amount of oxygen delivered and consumed by tissues, an thus of metabolic changes occurring in them [25, 32, 34]. Unfortunately, a common problem in the use of NIRS is difficulties in interpretation that result from diversity of indices and their units being used in measuring equipment. In the case of the apparatus being used by us, this index is $\mathrm{rSO}_{2}$ expressed in \%. Despite some limitations, many researchers believe that, due to the possibility of non-invasive and direct assessment of $\mathrm{rSO}_{2}$ in muscle capillary vessels, NIRS provides valuable information to evaluate the tissue condition [22, 26, 28, 32], owing to which NIRS can be an important tool for the objective assessment of physical training, planning of possible therapeutic strategies, and creation of rehabilitation protocols [24,35]. We did not find, however, any reports on the use of NIRS to assess the effect of physical therapy treatments and therefore an attempt was made to evaluate the suitability of its application to assess the treatments, being by design of hyperaemic and trophic nature. 
Some isolated evidence points out to the potential of using pressure waves in the treatment of many dysfunctions $[1,8,12$, $19,36]$; in practice, however, conclusive physiological improvement when using ultrasound and shockwave in controlled trials has not been definitively confirmed $[1,16,37]$. For this reason, the described therapeutic effect of pressure waves is sometimes based on hypotheses [4, 2, 37], and the obtained therapeutic effects are not fully explainable. In our study, we examined the ability of therapeutic sound waves to affect changes in haemoglobin and myoglobin oxidation in tissues at a depth of approximately $12.5-20 \mathrm{~mm}$ of the infraspinatus muscle region. When analysing the obtained results, it can be observed that significant changes with respect to regional oximetry were induced rapidly by the ultrasound treatment (Table 3), which can be confirmed by an immediate hyperaemic and hyperthermic effect of this physio-therapeutic procedure to deep tissues. The ability to measure local blood flow through a portion of tissue illuminated by NIRS light adds substantially to the information obtained on the adequacy of cellular oxygen provision. Blood flow is required to determine regional oxygen delivery and oxygen uptake $[21,24,25]$. These parameters may provide valuable insights into the basic mechanisms regulating microcirculatory $\mathrm{O}_{2}$ transport and tissue $\mathrm{O}_{2}$ utilisation in response to stimulation. Haemoglobin oxygen saturation $\left(\mathrm{SaO}_{2}\right)$ depends on: partial pressure of oxygen $\left(\mathrm{PaO}_{2}\right), 2,3$-diphosphoglycerate level in erythrocytes, blood $\mathrm{pH}$ and temperature, and the relationship between $\mathrm{SaO}_{2}$ and $\mathrm{PaO}_{2}$ in the body at blood $\mathrm{pH}=7.4$ and temperature of $37^{\circ} \mathrm{C}$ is shown by the oxyhaemoglobin dissociation curve [12]. An increase in temperature promotes de-dissociation of oxygen from haemoglobin, which is seen in the NIRS image as a decrease in $\mathrm{rSO}_{2}$ value [10]. In the presented study, a significant decrease was observed in $\mathrm{rSO}_{2} \%$ value, continuing $30 \mathrm{~min}$ after the UST treatment.

Taking into account the biophysical effects of sound waves proven in literature, which include thermal and mechanical effects, the most likely explanation of the changes being shown is an increased temperature in the stimulated tissue region. Affecting the tissues, primary mechanical ultrasound energy is gradually absorbed and converted into kinetic energy, and finally into heat. The literature presents evidence for UST inducing a rise in tissue temperature $[16,38,39]$. The extent of tissue heating depends on a number of variable factors, e.g. consistency of tissues, angle of incidence, particularly at their borders, vibrational frequency, and primarily on the intensity (sound power) being applied $[16,39,40,41]$. It is believed that the thermal effects of ultrasound treatment start when the value of sound power has exceeded $0.3 \mathrm{~W} / \mathrm{cm}^{2}$. The literature has documented the thermal effect of UST both in the context of animal and human studies. For example, the in vivo studies have shown the thermal effect of continuous therapeutic ultrasound inducing a temperature rise in the skin and deeper tissues and the fibrous capsule after treating a pig hip joint with ultrasounds. The dynamics of temperature rise depended to the greatest extent on ultrasound intensity; at $1.5^{-2.0} \mathrm{~W} / \mathrm{cm}^{2}$, the temperature increased only by $1^{\circ} \mathrm{C}$, whereas there was a clear rise in fibrous capsule temperature, even by $2-4^{\circ} \mathrm{C}$, at
2.5-3 W/cm ${ }^{2}$ after $1-3$ min of the treatment [39, 40, 41, 42]. The thermal effect of ultrasounds has been confirmed in human studies. Draper et al. [38], using the parameters similar to those applied in this study (Table 2 ), have shown a rise in gastrocnemius muscle temperature at a depth of $3 \mathrm{~cm}$ by $5^{\circ} \mathrm{C}$ after $10 \mathrm{~min}$ of ultrasound treatment with a continuous wave at $1.5 \mathrm{~W} / \mathrm{cm}^{2}$ and $1 \mathrm{MHz}$. The NIRS signal in human tissue is derived predominantly from the absorption of light by haemoglobin in small arterioles, capillaries and venules. According to our hypothesis, the heat generated during the treatment induces a reaction in the form of vasodilation and improvement of microcirculation, which increases the supply of oxygen to tissues, which - with simultaneous temperature rise and metabolism improvement - promotes its utilisation. According to the literature evidence, thermal and mechanical effects on the target tissue result in an increased local metabolism and microcirculation, promote re-perfusion and angiogenesis, reduce pain and muscle tension, inhibit muscle spasms, and accelerate healing $[16,27,43]$. Some researchers believe that these changes could account for the improved tissue repair which allegedly follows ultrasound therapy [44]. Taking into account the parameters of UST treatment being used in this study, based on the literature evidence, they confirm the thermal effect of this treatment and its beneficial consequences in the improvement of muscle tissue trophy. It seems that no skin hyperthermic effect being observed is mainly due to the fact that the operating frequency of ultrasound transducer was $0.8 \mathrm{MHz}$, which causes absorption of the sound wave energy at a depth of approximately 2-3 cm and, as is known, only the absorbed energy can induce the thermal effect and a rise in temperature $[40,41]$. The above observations are consistent with the assumption that the UST treatment less overheats shallow tissues than the deeper ones, and obtaining the rise in skin temperature would require application of maximum ultrasound intensities of approximately $3 \mathrm{~W} / \mathrm{cm}^{2}[1,8,18,40]$. At the same time, the need for application of a couplant during the treatment and its potential impact on skin surface cooling should be emphasised; nonetheless, lower skin temperature values of the analysed regions continued $30 \mathrm{~min}$ after the treatment. This in turn points to the principle of opposite reaction of superficial vessels in relation to the deep ones that results from sustained overheating of tissues at a depth of 2-3 cm. The depth of UST wave absorption is affected not only by the frequency being used but also the structure of stimulated tissue. Ultrasound waves are poorly absorbed by fluids (e.g. blood), somewhat intensely by soft tissues (e.g. adipose and muscle tissues), and fully absorbed by the tissues that contain large amounts of structural proteins (e.g. nervous tissue, cartilaginous tissue, and bone tissue). In addition, at the border of tissues with extreme absorption properties (e.g. bone and muscle tissues), the sound absorption is significantly higher than at the border of soft tissues (e.g. adipose and muscle tissues) $[1,7$, $8,13,14,15]$. The application of 2 sensor types allowed us to differentiate the measurement in relation to the reading depth to 20 and $12.5 \mathrm{~mm}$. The region chosen by us is characterised by the adipose fat layer located subcutaneously, and next by 
the muscle tissue layer (being characterised by small interindividual variation in terms of its thickness in non-training persons) and that of bone tissue of the infraspinous region. The border of the infraspinatus muscle and the infraspinous fossa is, as intended by the authors, the region with the highest absorption of UST waves, attributable at the same time to the depth of approximately $20 \mathrm{~mm}$. When comparing the readings from 2 sensors, it can be seen that decreased oxygen saturation occurred immediately after the treatment at a depth of $12.5 \mathrm{~mm}$, and only $15 \mathrm{~min}$ after the treatment at a depth of $20 \mathrm{~mm}$, lasting there longer (Table 3). As with UST, the therapeutic use of ESWT refers primarily to the effect on soft tissues. The therapeutic mechanism of shockwave therapy in musculoskeletal problems and the specific biological effects on various tissues (bone, cartilage, tendon and ligament) are not fully understood; the biological effects of stimulation have been postulated to decrease pain and muscle tension, inhibit muscle spasms, reduce oedema, accelerate healing, and dissolve calcified fibroblasts $[6,19,20]$. Despite its frequent use, firm evidence on its effectiveness from randomized controlled trials seems to be lacking. Some research indicates that ESWT also improved microcirculation and increased metabolism [6]. In large animal and human studies, ESWT has demonstrated the capacity to promote angiogenesis, tissue perfusion, and improvement in angina endpoints [27]. For example, Notarnicola et al. [37] assessed the effects of extracorporeal shockwave therapy on tissue perfusion in the treatment of tendinopathies. This study shows a statistically significant reduction in tissue oxygen saturation measured by oximetry, which correlated with clinical improvement of patients. It is believed that reduced perfusion can regulate inflammatory process and offset increased vascularisation [37]. In our study, we did not show any significant change in tissue oxygen saturation immediately after the single application of rESWT, nor to 30 min after it (Table 4). The studies cited above involve the application of full treatment series, which does not allow for a direct reference to the results being presented in them. No studies have been found that would evaluate the trophic effect with regional oximetry after the single application of rESWT. Additionally, we must notice, as has been shown, that pressure waves generated by rESWT cannot be called typical shockwaves because they lack the characteristic physical features of shockwaves [11]. The pressure wave produced by rESWT can reach speeds of about $20 \mathrm{~m} / \mathrm{s}$ which is not high enough to generate a real shockwave $[10,11]$. Most therapeutic effects of shockwave described in literature do not include their division into focused and radial ones but that they can potentially be the key to different observed stimulus effects. Radial extracorporeal shockwave therapy generates pressure waves by pneumatic or electromagnetic methods. Compressed air (or an electromagnetic field) is used to fire a projectile within a guiding tube that strikes a metal applicator placed on the patient's skin. The projectile generates stress waves in the applicator that transmit as pressure waves to the tissue [45]. The pressure wave is transmitted to the patient's skin through ultrasound gel and spreads as a spherical (radial) wave into the tissue. The energy is highest at the tip of the applicator and decreases peripherally by the square of the distance [36]. A significant increase in skin surface temperature immediately after the treatment is worth noting. The thermal effect is probably due to the intensive friction of applicator upon the skin surface and a noticeable post-treatment site reaction, resulting from superficial vasodilation. In addition, to avoid the effect of skin cooling, the rESWT treatment was performed without a couplant, which enhanced epidermal excoriation (Table 4). Perhaps, the demonstrated increase in temperature induced a decrease in oxygen saturation, similar to that in the UST treatment, but in the shallower tissues, however the NIRS sensor used by us does not read oxidation at a depth of less than $10 \mathrm{~mm}$. Although both UST and rESWT are a type of procedure using mechanical waves, the changes induced in tissue pressure are of different nature. Each shockwave in shockwave therapy consists of an approximately $1 \mu \mathrm{s}$-long, positive (compressional) pulse followed by a longer $(\sim 5 \mu \mathrm{s})$, lower amplitude negative (rarefactional) pressure pulse, while UST produces multiple cycles of a single-frequency (usually 1-10 MHz) sinusoidal ultrasound wave. Ultrasound therapy is a more flexible technology, as it allows adjustment of all acoustic treatment parameters to optimise non-thermal bio-effects. Shockwave therapy only allows control of pulse repetition frequency and amplitude [27]. The presented differences can be important in terms of the potentially obtained trophic effect [27]. However, the mechanism of achieving the trophic effect mediated by UST or ESWT is still not explained and is an active area of research, especially with respect to a series of treatments.

To sum up, it is worth noting that although UST and rESWT belong to the same group of sound stimuli, their effects on metabolism, being measured by tissue oxygen saturation, does not proceed in the same way, most probably with the varied dynamics influence. Our initial hypothesis, i.e. the assumption of a potentially stronger trophic effect of rESWT for the muscle tissue, resulting from the more intense post-treatment reaction, can not be clearly confirmed. The magnitude and direction of changes in regional oximetry seem to be similar with respect to the level in the muscle tissue being recorded by a sensor from a depth of $20 \mathrm{~mm}$ although the effect occurs earlier following the application of UST (as early as after $15 \mathrm{~min}$ ) than following rESWT (after $30 \mathrm{~min}$ ). In addition, the application of UST induces a change in metabolism of the shallower tissues, which we did not observe after the application of rESWT.

\section{CONCLUSIONS}

The NIRS method is a useful tool to assess tissue oxygen saturation following the stimulation with mechanical waves. The single UST application decreases the value of oxygen saturation to $30 \mathrm{~min}$ after the treatment. The decrease in oxygen saturation is presumably the result of a temperature rise in the deeper tissues, promoting the de-dissociation of oxygen from haemoglobin and inducing the trophic effect. The single rESWT stimulation induces a change in oxygen saturation in 
the 30-minute post-treatment period being assessed. Following the UST treatment, skin surface temperature of the stimulated region decreases, which the result of direct contact with a cool couplant. The rESWT treatment performed without acouplant induces a temporary rise in skin surface temperature.

\section{REFERENCES}

1. Paliwal S, Mitragotri S. Therapeutic opportunities in biological responses of ultrasound. Ultrasonics 2008;48(4):271-8. doi: 10.1016/j. ultras.2008.02.002.

2. Miller DL, Smith NB, Bailey MR, Czarnota GJ, Hynynen K, Makin IR. Overview of therapeutic ultrasound applications and safety considerations. J Ultrasound Med 2012;31(4):623-34.

3. Alexander LD, Gilman DR, Brown DR, Brown JL, Houghton PE. Exposure to low amounts of ultrasound energy does not improve soft tissue shoulder pathology: a systematic review. Phys Ther 2010;90(1):14-25. doi: 10.2522/ptj.20080272.

4. Robertson VJ, Baker KG. A review of therapeutic ultrasound: effectiveness studies. Phys Ther 2001;81(7):1339-50.

5. Suslick KS. Ultrasound: its chemical, physical, and biological effects. Science 1989;243(4897):1499.

6. ter Haar GS, Daniels S. Evidence for ultrasonically induced cavitation in vivo. Phys Med Biol 1981;26(6):1145-9.

7. Feril LB, Kondo T. Biological effects of low intensity ultrasound: the mechanism involved, and its implications on therapy and on biosafety of ultrasound. J Radiat Res 2004;45(4):479-89.

8. Gutierrez MI, Lopez-Haro SA, Vera A, Leija L. Experimental verification of modeled thermal distribution produced by a piston source in physiotherapy ultrasound. Biomed Res Int 2016;2016:5484735. doi: $10.1155 / 2016 / 5484735$.

9. Marks R, Ghanagaraja S, Ghassemi M. Ultrasound for osteo-arthritis of the knee: a systematic review. Physiotherapy 2000;86(9):452-63. doi: 10.1016/s0031-9406(05)60807-3.

10. Ke MJ, Chen LC, Chou YC, Li TY, Chu HY, Tsai CK, et al. The dose-dependent efficiency of radial shock wave therapy for patients with carpal tunnel syndrome: a prospective, randomized, single-blind, placebo-controlled trial. Sci Rep 2016;6:38344. doi: 10.1038/srep38344.

11. van der Worp H, van den Akker-Scheek I, van Schie H, Zwerver J. ESWT for tendinopathy: technology and clinical implications. Knee Surg Sports Traumatol Arthrosc 2013;21(6):1451-8. doi: 10.1007/s00167-012-2009-3.

12. Signori LU, Costa ST, Neto AF, Pizzolotto RM, Beck C, Sbruzzi G, et al. Haematological effect of pulsed ultrasound in acute muscular inflammation in rats. Physiotherapy 2011;97(2):163-9. doi: 10.1016/j.physio.2010.06.004.

13. Demchak TJ, Stone MB. Effectiveness of clinical ultrasound parameters on changing intramuscular temperature. J Sport Rehabil 2008;17(3):220 9. doi: 10.1123/jsr.17.3.220.

14. Grey K. Distribution of treatment time in physiotherapeutic application of ultrasound. Physiotherapy 2003;89(12):696-707. doi: 10.1016/S00319406(05)60492-0.

15. Warden SJ, McMeeken JM. Ultrasound usage and dosage in sports physiotherapy. Ultrasound Med Biol 2002;28(8):1075-80. doi: 10.1016/S03015629(02)00552-5.

16. Baker KG, Robertson VJ, Duck FA. A review of therapeutic ultrasound: biophysical effects. Phys Ther 2001;81(7):1351-8.

17. Speed CA. Therapeutic ultrasound in soft tissue lesions. Rheumatology (Oxford) 2001;40(12):1331-6.

18. ter Haar G. Therapeutic ultrasound. Eur J Ultrasound 1999;9(1):3-9. doi: 10.1016/S0929-8266(99)00013-0.

19. Lubkowska A, Dobek A. Clinical application of radial and focused shock wave therapy in painful shoulder syndrome. Fizjoter Pol 2013;13(1):36-43.

20. Lubkowska A, Dobek A, Garczyński W, Andryszczyk M, Rotter I. Evaluation of the functional status of patients with a diagnosis of painful shoulder before and after a series of 3 radial shock wave treatment. J Health Sci 2014;4(4):89-101.

21. Jones S, Chiesa ST, Chaturvedi N, Hughes AD. Recent developments in near-infrared spectroscopy (NIRS) for the assessment of local skeletal muscle microvascular function and capacity to utilise oxygen. Artery Res 2016;16:25-33. doi: 10.1016/j.artres.2016.09.001.

22. Trafidło T, Gaszyński T, Gaszyński W, Nowakowska-Domagała K. Intraoperative monitoring of cerebral NIRS oximetry leads to better postoperative cognitive performance: a pilot study. Int J Surg 2015;16(Pt A):23-30. doi: 10.1016/j.ijsu.2015.02.009.

23. Casati A, Spreafico E, Putzu M, Fanelli G. New technology for noninvasive brain monitoring: continuous cerebral oximetry. Minerva Anestesiol 2006;72(7-8):605-25.

24. Figoni SF, Kunkel CF, Scremin AM, Asher A, Banks NL, Rivera A, et al. Effects of exercise training on calf tissue oxygenation in men with claudication. PM R 2009;1(10): 932-40. doi: 10.1016/j.pmrj.2009.08.453.

25. Manfredini F, Lamberti N, Malagoni AM, Zambon C, Basaglia N, Mascoli F, et al. Reliability of the vascular claudication reporting in diabetic patients with peripheral arterial disease: a study with near-infrared spectroscopy. Angiology 2015;66(44):365-74. doi: 10.1177/0003319714534762.

26. Southern WM, Ryan TE, Kepple K, Murrow JR, Nilsson KR, McCully KK. Reduced skeletal muscle oxidative capacity and impaired training adaptations in heart failure. Physiol Rep 2015;3(4):pii:e12353. doi: 10.14814/ phy2.12353.

27. Nazer B, Ghahghaie F, Kashima R, Khokhlova T, Perez C, Crum L, et al. Therapeutic ultrasound promotes reperfusion and angiogenesis in a rat model of peripheral arterial disease. Circ J 2015;79(9):2043-9. doi: 10.1253/ circj.CJ-15-0366.

28. Krosny T, Dąbek P, Staszkewicz W, Lewszuk A. Assessment of perfusion abnormalities in patients with p.o.d. using NIRS (near infrared spectroscopy). Post Nauk Med 2012;8(15):628-35.

29. Fowkes FG, Housley E, Cawood EH, Macintyre CC, Ruckley CV, Prescott RJ. Edinburgh Artery Study: prevalence of asymptomatic and symptomatic peripheral arterial disease in the general population. Int J Epidemiol 1991;20(2):384-92.

30. Hagblad J, Lindberg LG, Kaisdotter Andersson A, Bergstrand S, Lindgren M, Ek AC, et al. A technique based on laser Doppler flowmetry and photoplethysmography for simultaneously monitoring blood flow at different tissue depths. Med Biol Eng Comput 2010;48(5):415-22. doi: 10.1007/ s11517-010-0577-2.

31. Lenasi H, Potočnik N, Petrishchev N, Papp M, Egorkina A, Girina M, et al. The measurement of cutaneous blood flow in healthy volunteers subjected to physical exercise with ultrasound Doppler imaging and laser Doppler flowmetry. Clin Hemorheol Microcirc 2017;65(4):373-81. doi: 10.3233/CH-16204.

32. Celie BM, Boone J, Dumortier J, Derave W, De Backer T, Bourgois JG. Possible influences on the interpretation of Functional Domain (FD) Near-Infrared Spectroscopy (NIRS): an explorative study. Appl Spectrosc 2016;70(2):363-71. doi: 10.1177/0003702815620562.

33. Boushel R, Piantadosi C. Near-infrared spectroscopy for monitoring muscle oxygenation. Acta Physiol Scand 2000;168(4):615-22. doi: 10.1046/j.1365201x.2000.00713.x.

34. Cuisset T, Quilici J, Pankert M, Fourcade L, Poyet R, Lambert M, et al. Usefulness of index of microcirculatory resistance to detect microvascular dysfunction as a potential mechanism of stress-induced cardiomyopathy (Tako-tsubo syndrome). Int J Cardiol 2011;153(3):e51-3. doi: 10.1016/j. ijcard.2011.02.028.

35. Palanca AA, Yang A, Bishop JA. The effects of limb elevation on muscle oxygen saturation: a near-infrared spectroscopy study in humans. PM R 2016;8(3):221-4. doi: 10.1016/j.pmrj.2015.07.015.

36. Malliaropoulos N, Jury R, Pyne D, Padhiar N, Turner J, Korakakis V, et al. Radial extracorporeal shockwave therapy for the treatment of finger tenosynovitis (trigger digit). Open Access J Sports Med 2016;7:143-51. doi: 10.2147/OAJSM.S108126.

37. Notarnicola A, Moretti L, Tafuri S, Forcignanò M, Pesce V, Moretti B. Reduced local perfusion after shock wave treatment of rotator cuff tendinopathy. Ultrasound Med Biol 2011;37(3):417-25. doi: 10.1016/j. ultrasmedbio.2010.11.019.

38. Draper DO, Sunderland S, Kirkendall DT, Ricard M. A comparison of temperature rise in human calf muscle following applications of underwater and topical gel ultrasound. J Orthop Sports Phys Ther 1993;17(5):247-51. doi: 10.2519/jospt.1993.17.5.247.

39. Lehmann JF, McMillan JA, Brunner GD, Blumberg JB. Comparative study of the efficiency of short-wave, microwave and ultrasonic diathermy in heating the hip joint. Arch Phys Med Rehabil 1959;40:510-2. 
40. ter Haar G, Hopewell JW. Ultrasonic heating of mammalian tissues in vivo. Br J Cancer 1982;45(Suppl V):65-7.

41. Lehmann JF, de Lateur BJ. Therapeutic heat. In: Lehmann JF, editor Therapeutic heat and cold. Baltimore: Williams \& Wilkins; 1990. p. 417-581.

42. Johns LD, Colloton P, Neuenfeldt J, Krupo K. Pre-exposure effects of 1 and $3 \mathrm{MHz}$ therapeutic ultrasound on ConA activated spleenocytes. Cytokine 2003;22(3-4):55-61.
43. van der Windt DA, van der Heijden GJ, van den Berg SG, ter Riet G, de Winter AF, Bouter LM. Ultrasound therapy for musculoskeletal disorders: a systematic review. Pain 1999;81(3):257-71.

44. Dyson M. Mechanisms involved in therapeutic ultrasound. Physiotherapy 1987;73(3):116-20.

45. Császár NB, Angstman NB, Milz S, Sprecher CM, Kobel P, Farhat M, et al. Radial shock wave devices generate cavitation. PLoS One 2015;10(10):e0140541. doi: 10.1371/journal.pone.0140541. 